\title{
Effects of Misinformation on the Stock Return: A Case Study
}

\author{
A. F. M. Mainul Ahsan ${ }^{1, *}$, Mohammad Osman Gani ${ }^{1}$, Md. Bokhtiar Hasan ${ }^{2}$ \\ ${ }^{1}$ Dept. of Economics, School of Business, Independent University, Bangladesh (IUB), Dhaka, Bangladesh \\ ${ }^{2}$ Development \& Information Department, Dhaka Stock Exchange Limited, Dhaka, Bangladesh \\ *Corresponding Author: mainul188@gmail.com
}

Copyright (C) 2013 Horizon Research Publishing All rights reserved.

\begin{abstract}
Information affects stock prices, even if it is not truthful. The news piped through the business press may contain deliberately planted misinformation. This study examines the effect of erroneous news and analysis by a leading daily newspaper on the performance of stock returns in the Dhaka Stock Exchange in Bangladesh. The reaction to the false news involves an unsustained jump in stock prices under misguided optimism. We also investigate the scope of legal remedies against false news and stock price manipulation. The responsibility and accountability of the media involved in spreading misinformation is also an issue.
\end{abstract}

Keywords Misinformation, Bank Company Act, Banking Sector

\section{Introduction}

In the stock market, investors are deluged with a variety of information. On a daily basis, they receive firms' earnings reports, revisions of macroeconomic indexes, policymakers' statements, and political news. These pieces of information are processed by investors to update their projections of the economy's future growth rate, inflation rate, interest rate and policy direction. In turn, these changes in investors' expectations affect stock prices. However, although there is an enormous amount of news and information available in the marketplace, the quality may be debatable. Investors may not always be able to judge the correctness of the news. Indeed, manipulation is possible if the uncritical investors react to deliberate misinformation as if the news were true. This phenomenon of reaction to false news raises serious questions about the behavior of the stock market. It would undermine the efficient market hypothesis (EMH), for example.

In an attempt to investigate reasons behind low quality business report on the newspapers, Jensen (1977) pointed to lack of analysis and economic knowledge held by correspondents. He continues to explain how newspapers and the greater part of media seek to deliver entertainment that sells. The same thing is applicable in a frontier market like Bangladesh.

On October 2, 2012, the headline on the first page of the daily Financial Express was 'Banks' stock market exposure set at 40\%, BB denied control over SCBs" (Figure 1). The news basically reported that in the proposed amendments to the Bank Company Act (BCA), 1991, the maximum limit of a bank's exposure to the capital market has been set at $40 \%$ of the total paid-up capital of a bank. On October 3, other leading newspapers like the daily Prothom Alo, The daily Star also had news on this subject and said that this decision will benefit the stock market in Bangladesh as banks will be able to invest more, once the amendment comes into effect. Unfortunately, the news and the analysis were utterly incorrect. This study examines the effect of false news, i.e., misinformation, and misguided analysis by a leading daily newspaper on the performance of stock returns in a frontier market in Bangladesh.

There are two major implications of this phenomenon: (1) First, theoretically it raises the possibility that clever manipulators can plan sporadic misinformation to inflate or deflate prices unduly, and thereby undermine the efficiency of the market.

(2) Secondly, in practice, there is a serious question of regulatory control to limit the placement of misinformation for the mala-fide purpose of cheating innocent investors. Though it is not possible to offer solutions of the above issues without much multidisciplinary work, the paper begins a search for questions regarding the possibility of deliberate misinformation to manipulate stock prices. This paper is a case study of misinformation affecting the stock market in Bangladesh.

Section 2 of this study lists previous studies related to news from the popular press and its impact on the stock market. Section 3 describes data collection. Section 4 discusses results of the research. Section 5 provides legal remedies available against false news in Bangladesh. Lastly, section 6 provides concluding remarks on the study with a note on media accountability. 


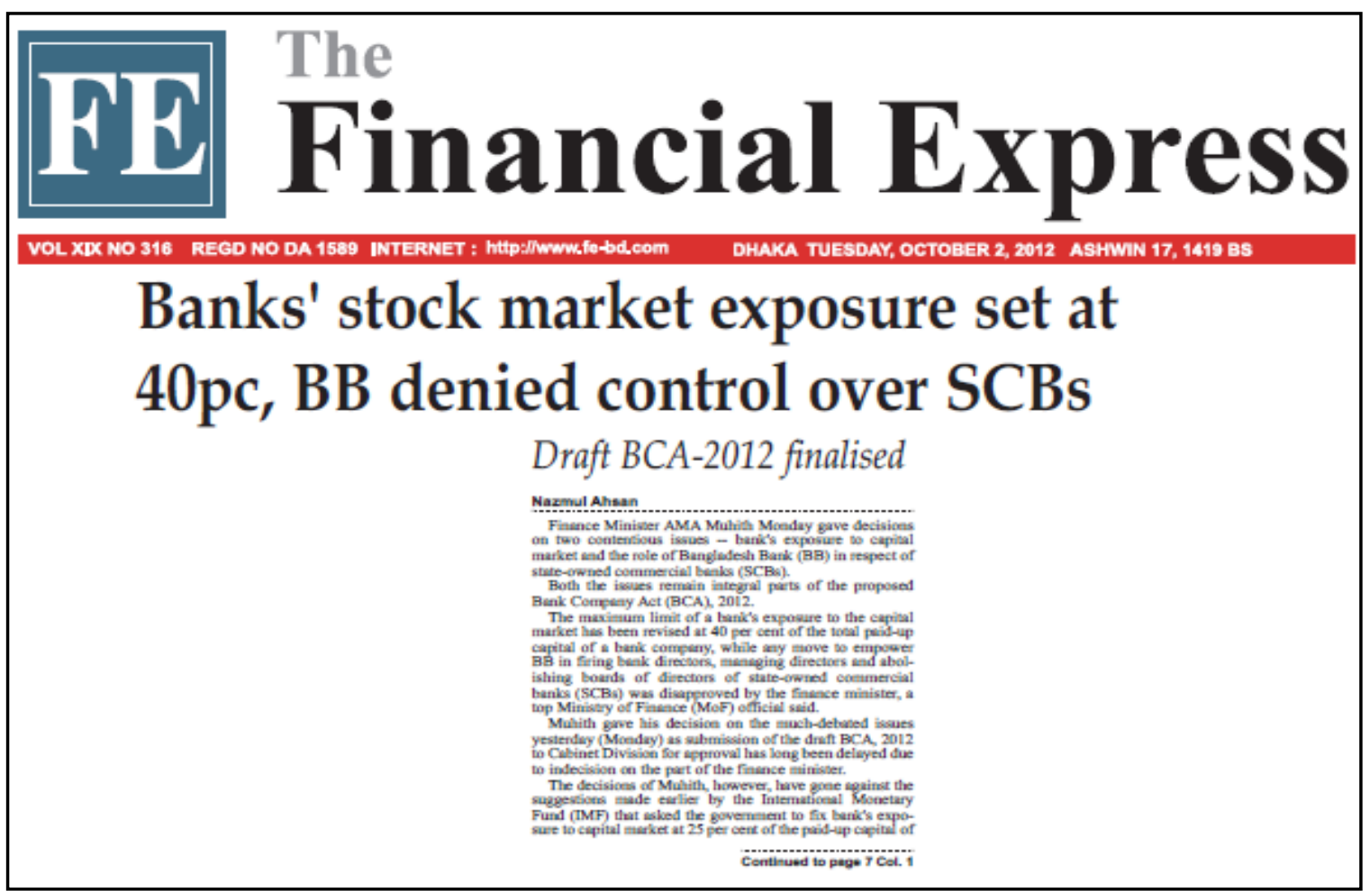

Figure 1. Headline in the first page of the daily Financial Express on October 2nd, 2012

\section{Literature Review}

There is practically no mention of stock market manipulation through deliberate planting of misinformation in Bangladesh. However, elsewhere in the world, a voluminous literature examined the issues of investor reaction to news.

The very first research to understand the impact of news on wild movements in stock prices can be traced back to Niederhoffer (1971). He examined the short-term impact of world events on the stock market. In his analysis, Niederhoffer tried to understand how different world events contribute to movements in the S\&P 500. His sample events are selected from the New York Times based on the magnitude of their headlines. Results of Niederhoffer's work show that world events affect movement of the S\&P 500; specifically, returns subsequent to different world events tend to be higher in absolute term comparing to returns on other days.

Cutler, Poterba and Summers (1989) examined market reactions subsequent to 49 cautiously chosen events. They found that the average absolute value of daily returns on the whole sample dates are $1.46 \%$ with standard deviation of $2.08 \%$. Conversely, the average absolute value of returns on other days, i.e., non-event days, from 1941-1987 was 0.56\% while the standard deviation is $0.83 \%$. However, Cutler et al. (1989) claimed that these numbers cannot describe enough the "missing variation" in stock returns. However, a comparison of standard deviations show that returns on the event days are more volatile when compared with the returns on the non-event days.
Mitchell and Mulherin (1994) examined the connection between Dow Jones news announcements and stock returns. They discovered that Dow Jones announcements have a direct impact on different securities market activities including trading volume and market returns.

Kim and Mei (1994) investigated how political events contribute in the movements in the Hong Kong stock market. Using an event-study methodology, they showed that political developments have a significant influence on the stock returns. They also illustrated that adding a political variable to the regression equations improves these models' explanatory power.

Desai and Jain (1995) studied the performance of recommendations on stocks done by well-known fund managers at the annual Barron's Roundtable during 1968 to 1991. The buy recommendations produced sizeable abnormal returns from the recommendation date to the publication day, a window of about 14 days.

Falkenstein (1996) noticed that mutual fund managers have strong fondness for stocks with greater visibility, as measured by the amount of financial press coverage.

Huberman and Regev (2001) examined the trading volume and stock price of EntreMed, involved in developing therapeutics to treat cancer and other diseases, (ticker: ENMD) that gained 28.4 percent on the day when a Times article reported on a new cancer drug from that company, even though the same article had been published in Nature and other newspapers five months earlier. They concluded that media coverage can influence both the volume and pricing of a security simply by getting attention to it. 
Chan (2003) studied the monthly stock returns of firms influenced by the headlines of news pertaining to these firms. $\mathrm{He}$ found that negative articles yield in a negative drift in stock prices up to next 12 months. Also stocks that suffered negative returns because of a news article continued to underperform their peers.

Ferreira and Smith (2003) conducted a study to determine the impact of recommendations made in a television show called "Wall Street Week with Louis Rukeyser" in 1997. They found that the portfolio of stocks under investigation improved in value in the following eight quarters. Furthermore they also found that the increase in value was higher than for the matched sample in all eight quarters.

Doong, Yang and Chiang (2005) concluded that shareholders in Asian markets usually react substantially to negative news coming from the U.S. sources comparing to positive news.

Takeda and Yamazaki (2006) took a further step by studying the relations between the stock price of a firm and the exposure of a firm in Japan's popular TV program, "Project X", on NHK channel from 2000 to 2005. Using standard event study methodology, they noticed that stock prices of these firms soared after the broadcast of the show. One fascinating result of this research is that a simple report of a firm's old story still has a positive impact on its stock return.

Tetlock (2007) used news articles from the Wall Street Journal to assess the impact of media on the stock market. He found the soaring media pessimism leads to lower stock returns, and high trading volume. Lloyd-Davies and Canes (1978), Beneish (1991), Barber and Loeffler (1993) and Liang (1999) detected superior performance from suggestions made on the "Heard on the Street" and "Dartboard" columns printed on the Wall Street Journal.

Arnold, Earl and North (2007) found that positive cover page stories can be correlated to positive stock performance. The same argument holds true for negative news, i.e., correlation between negative news and negative stock performance. Arnold et al. (2007) analyzed companies that were subject of 549 feature stories in the Business Week, Fortune and Forbes magazine during the period between 1983 and 2002. They found a link between positive cover page stories and positive stock performance. The reverse situation was also found to be true.

Yuan (2008) found that market-wide attention-grabbing events, for instance, record-breaking events of the Dow index and front page articles about the stock market, affect the trading behavior of individual investors and stock market returns.

Fang and Peress (2009) studied the relation between the average stock return of certain firms and their media coverage in a period, and found that stocks not covered by the media earn significantly higher returns than stocks that are strongly covered, even after controlling for well-known risk characteristics.

Tetlock (2010) claimed that financial media plays a vital role in solving the problem of information asymmetry in the marketplace.

Solomon, Soltes \& Sosyura (2012) showed that media coverage affects investors' capital allocations to mutual funds. Investors reward funds that hold stocks with high past returns, but only if these stocks recently received media coverage. They argued that investors, when faced with a long list of fund holdings, appear to respond only to those companies which were recently featured in the news. As a result, funds holding high-visibility winners attract greater capital flows than their counterparts holding less visible stocks.

\section{Data}

There are total 30 banks are listed on the Dhaka Stock Exchange (DSE) in Bangladesh. Data on different balance sheet items, for instance, total liability, paid up capital, share premium, statutory reserve, and total equity, of the listed all the 30 banks for the year 2011 have been collected from the DSE library.

\section{Actual Proposed Amendment and Analysis}

The news was faulty on two counts. First, it failed to report the real information that was proposed to the Bank Company Act (BCA), 1991. Second, the analysis and prediction in the report was totally opposite of reality.

\subsection{Actual Proposed Amendment}

The existing exposure limit to stock market of a bank is $10 \%$ of its total liabilities as stipulated in the existing BCA (amended), 2003. All these dailies, i.e., the daily Financial Express, the daily Star and the daily Prothom Alo, basically reported that in the proposed amendments to the Bank Company Act (BCA), 1991, the maximum limit of a bank's exposure to the capital market has been set at $40 \%$ of the total paid-up capital of a bank (Image 1). In reality, none of the newspapers provided the correct information on the proposed amendment. So, a clarification was needed. The proposed amendment says that banks will be able to invest in the stock market by $40 \%$ of the sum of their total paid-up capital, share premium and statutory reserve, not only paid-up capital.

All these three elements -- total paid-up capital, share premium and statutory reserve -- are subset of the total equity item on the balance sheet. Total equity component of a bank can include many other items beyond those three elements. Retained earnings, revaluation reserve, preference share capital, and other reserve are few examples of some other significant items in the equity portion on the balance sheet of a bank operating in Bangladesh. Many times, banks' statutory reserve could be higher than paid-up capital. For a bank, share premium could be zero to any amount. 


\subsection{What Will Happen if Proposed Amendment Comes in Effect?}

Reporters of those newspapers believed that setting banks' stock market exposure at " $40 \%$ of total equity" would increase banks' investment in the stock market. But data don't support that conclusion. Because of the nature of the business, banks' total liability is much higher than its paid-up capital or even total equity. Table 1 reports median values of total liability, paid-up capital, statutory reserve and share premium of all the listed banks in Bangladesh. While median total liability for all the sample banks is tk. 98,760,162,160, the median total equity for the same sample is tk. $9,648,986,796$ which is $9.77 \%$ of the median total liability. On other hand, median paid-up capital of all the listed banks in Bangladesh is tk. 4,527,257,670 which is $4.58 \%$ of the median total liability of the same sample.
Table 1. Median value of some components from the balance sheet

\begin{tabular}{|c|c|}
\hline Particulars & Amount (tk) \\
\hline Median Total Liability of listed Banks & $152,725,371,464$ \\
\hline Median Total Paid up Capital & $4,527,257,670$ \\
\hline Median Total Share Premium & 0.00 \\
\hline Median total Statutory Reserve & $2,815,129,127$ \\
\hline Median Total equity of listed Banks & $9,648,986,796$ \\
\hline
\end{tabular}

In Bangladesh, currently a bank can invest maximum of $10 \%$ of its total liabilities in the stock market. Table 2 presents information on total liability, paid up capital, share premium, statutory reserve, and total equity of the listed banks. For 13 banks, out of $30,10 \%$ of the total liability is even greater than total equity.

Table 2. Listed banks' Liability, Paid up Capital, Share Premium, Statutory Reserve, Equity(All amounts in thousands taka)

\begin{tabular}{|c|c|c|c|c|c|c|}
\hline & Bank Name & Total Liability & $\begin{array}{c}\text { Paid } \\
\text { Up Capital }\end{array}$ & $\begin{array}{c}\text { Share } \\
\text { Premium }\end{array}$ & $\begin{array}{c}\text { Statutory } \\
\text { Reserve }\end{array}$ & Total Equity \\
\hline 1 & AB Bank & $139,389,318$ & $3,686,114$ & - & $4,390,197$ & $15,015,433$ \\
\hline 2 & Al-Arafah & $94,779,072$ & $5,893,372$ & - & $2,372,832$ & $11,989,109$ \\
\hline 3 & Bank Asia & $105,537,522$ & $5,254,791$ & 0 & $2,959,359$ & $12,605,986$ \\
\hline 4 & BRAC Bank & $123,598,000$ & $3,212,000$ & $1,406,000$ & $2,536,431$ & $9,603,000$ \\
\hline 5 & City Bank & $98,208,255$ & $5,055,111$ & $1,924,635$ & $2,670,899$ & $17,914,710$ \\
\hline 6 & Dhaka Bank & $95,743,417$ & $3,590,457$ & - & $3,284,607$ & $9,293,797$ \\
\hline 7 & Dutch-Bangla & $113,912,511$ & $2,000,000$ & 11,068 & $3,657,698$ & $8,941,336$ \\
\hline 8 & Eastern Bank & $103,173,668$ & $4,527,258$ & - & $3,551,351$ & $14,407,051$ \\
\hline 9 & Exim Bank & $115,240,334$ & $9,223,563$ & - & $3,849,776$ & $14,469,483$ \\
\hline 10 & First Security & $86,456,468$ & 340,032 & - & 704,202 & $4,500,173$ \\
\hline 11 & ICB Islami & $25,616,055$ & $6,647,023$ & - & 78,811 & $(7,600,892)$ \\
\hline 12 & IFIC Bank & $85,111,587$ & $2,768,379$ & - & $2,547,828$ & $6,685,173$ \\
\hline 13 & Islami Bank & $361,761,849$ & $10,007,712$ & - & $10,004,427$ & $27,613,755$ \\
\hline 14 & Jamuna Bank & $79,864,904$ & $3,648,404$ & - & $1,723,459$ & $7,302,830$ \\
\hline 15 & Mercantile & $106,893,681$ & $4,968,092$ & - & $2,643,394$ & $9,659,333$ \\
\hline 16 & Mutual Trust & $71,669,469$ & $2,543,498$ & - & $1,473,577$ & $4,834,348$ \\
\hline 17 & National Bank & $146,992,831$ & $8,603,656$ & - & $6,058,642$ & $21,562,552$ \\
\hline 18 & NCCBL & $92,061,919$ & $5,941,654$ & - & $3,269,493$ & $11,621,813$ \\
\hline 19 & One Bank & $61,456,742$ & $3,188,676$ & - & $1,898,008$ & $6,171,170$ \\
\hline 20 & Premier Bank & $68,277,701$ & $3,818,611$ & - & $1,800,273$ & $6,673,406$ \\
\hline 21 & Prime Bank & $180,811,769$ & $7,798,096$ & $2,241,230$ & $5,778,120$ & $19,138,725$ \\
\hline 22 & Pubali Bank & $140,882,347$ & $6,707,610$ & - & $5,230,776$ & $16,408,874$ \\
\hline 23 & Rupali Bank & $129,585,521$ & $1,375,000$ & - & $2,035,092$ & $15,250,791$ \\
\hline 24 & Shahjalal Isla. & $99,312,069$ & $4,452,655$ & - & $2,252,105$ & $7,916,793$ \\
\hline 25 & Social Islami & $74,603,312$ & $6,393,926$ & - & $6,393,926$ & $9,358,334$ \\
\hline 26 & South East & $138,694,628$ & $8,317,008$ & - & $4,519,282$ & $19,376,302$ \\
\hline 27 & Standard Bank & $68,082,483$ & $4,061,320$ & - & $1,995,156$ & $6,870,527$ \\
\hline 28 & Trust Bank & $71,172,376$ & $2,661,127$ & - & $1,827,243$ & $5,863,652$ \\
\hline 29 & Uttara Bank & $87,680,089$ & $2,875,173$ & - & $2,980,837$ & $9,638,640$ \\
\hline \multirow[t]{2}{*}{30} & UCBL & $152,725,371$ & $7,274,884$ & $1,454,977$ & $3,594,278$ & $15,963,172$ \\
\hline & Total & $3,319,295,267$ & $146,495,170$ & $7,037,910$ & $91,377,727$ & $339,049,375$ \\
\hline
\end{tabular}


Graph 1 presents how does the market also responded immediately to that "false" news. On October $2^{\text {nd }}$ when the financial express made the fake headline about increasing banking sector's investment capacity, investors invested heavily in the banking sector. On October 2, DSE All Share Price Index (DSI) increased $2.52 \%$, or 98 points. Out of $2.52 \%$ positive change in DSI Index, $55.08 \%$ (or 54 points) of total variation is caused by the banking sector alone. On October 3 , a leading newspaper, the daily Star, also confirmed the effect of that forged news and wrote: "Stocks gained for the second day, riding on investors' optimism fuelled by the newly set exposure limit of commercial banks in the stock market."

However, the market is smart. It found the loophole and quickly adjusted as necessary, which was reflected in the subsequent market returns. On October $3^{\text {rd }}$, the DSI Index dropped $0.88 \%$ (or 35 points) out of which $64 \%$ of the decline is caused by the banking sector. In fact, after the October 2 market rise, stock market declined for the next 4 consecutive business days. Table 3 presents details of the fluctuations in the DSI Index because of the false news by business press.

Table 4 presents summary of impact of proposed amendments in Bank Company Act (BCA), 1991. If the proposed amendment takes place, as per annual report of 2011, banking sector will be able to invest tk. $97,964,322,951$ which is $29.51 \%$ of existing capacity. Rather than increasing investment in the stock market, proposed amendment will actually reduce banking sector's investment capacity by $70.49 \%$. So, if proposed amendment comes into effect, it will actually force banks to reduce their investment in the stock market substantially.

However, International Monetary Fund (IMF) proposed Bangladesh government to allow banks to invest maximum $25 \%$ of their paid up capital, share premium and statutory reserve. And if that becomes the case, the banking sector will be able to invest tk. $61,227,701,844$ which is $18.45 \%$ of existing capacity. Thus, this proposed amendment will actually reduce banking sector's investment capacity by $81.55 \%$.

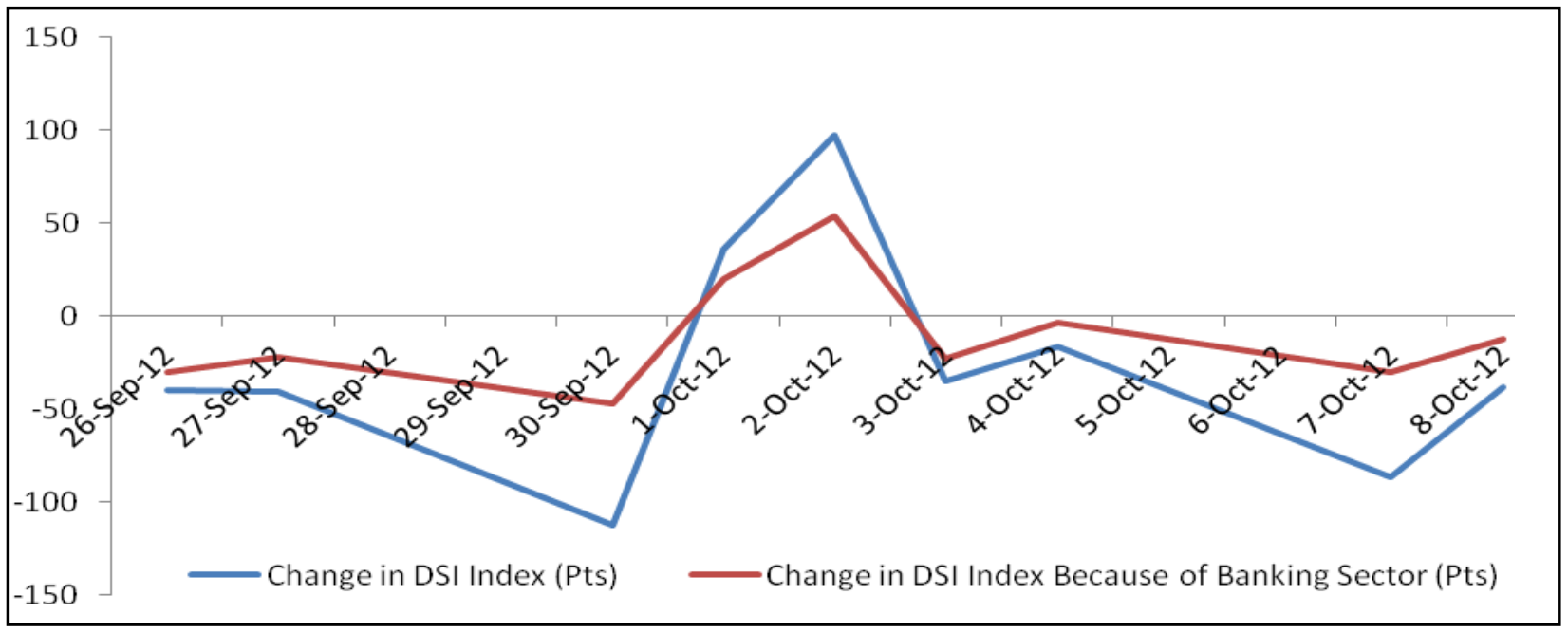

Graph 1. Market reaction "false" news

Table 3. Effect of false news by a newspaper on the DSI Index and the Banking Sector

\begin{tabular}{|c|c|c|c|}
\hline & $\begin{array}{c}\text { Change in DSI } \\
\text { Index (Pts) }\end{array}$ & $\begin{array}{c}\text { Change in DSI Index } \\
\text { because of Banking } \\
\text { Sector (Pts) }\end{array}$ & $\begin{array}{c}\frac{\text { \%o of the change in the }}{\text { DSI Index is contributed by }} \\
\text { the Banking Sector }\end{array}$ \\
\hline September 26, 2012 & $(39.51)$ & $(30.00)$ & $(75.93)$ \\
\hline September 27, 2012 & $(40.84)$ & $(22.22)$ & $(54.41)$ \\
\hline September 30, 2012 & $(112.21)$ & $(47.27)$ & 54.61 \\
\hline October 1, 2012 & 35.99 & 19.66 & 55.08 \\
\hline October 2, 2012 & 97.69 & 53.80 & $(64.10)$ \\
\hline October 3, 2012 & $(35.05)$ & $(22.47)$ & $(18.95)$ \\
\hline October 4, 2012 & $(16.58)$ & $(3.14)$ & $(34.69)$ \\
\hline October 7, 2012 & $(86.42)$ & $(29.98)$ & $(32.37)$ \\
\hline October 8, 2012 & $(38.11)$ & $(12.33)$ & \\
\hline
\end{tabular}


Table 4. Effect of proposed amendments in Bank Company Act (BCA), 1991

\begin{tabular}{|c|c|}
\hline Particulars & $\begin{array}{c}\text { Taka } \\
\text { (in thousands) }\end{array}$ \\
\hline Total Liability of listed Banks & $3,319,295,267$ \\
\hline Total Paid Up Capital, Share Premium, Statutory Reserve & $244,910,807$ \\
\hline Total equity of listed Banks & $339,049,375$ \\
\hline $10 \%$ of total Liability of listed Banks & $331,929,527$ \\
\hline $40 \%$ of total equity of listed Banks & $135,619,750$ \\
\hline $40 \%$ of total of Paid Up Capital, Share Premium, Statutory Reserve & $97,964,323$ \\
\hline $25 \%$ of total of Paid Up Capital, Share Premium, Statutory Reserve & $61,227,702$ \\
\hline
\end{tabular}

\section{Remedy in Existing Law}

The story points out two issues: one, the market is vulnerable to misinformation, though it eventually recovers, and the second is that there was severe regulatory failure.

In the above, we have shown how the market responded to that erroneous news and analysis. The serious issue is that innocent investors may be taken for a wild ride in which they stand to lose to manipulators masked behind the misinformation. Economists and legal experts need to work together to develop a framework to analyze wrongful misinformation. The key goal of the analysis is to identify excess volatility induced by false news and to measure the damage done through undue transfer of wealth from gullible investors.

The problem for the legal profession is to prepare a proper procedure for prosecution of the wrongdoers. This is also a challenging problem in which economics and law have to work together.

On the surface, there is evidence of regulatory failure. None of the regulatory organizations -- Bangladesh Bank, Securities and Exchange Commission (SEC), Dhaka Stock Exchange (DSE) -- came up with a proper explanation of the proposed amendments in the Bank Company Act (BCA), and ultimately general investors had to pay the price. Also, no actions have been taken yet against the journalist or related parties who wrote or published that faulty news and analysis. However, existing law provides scope for actions for creating and disseminating faulty news and analysis.

Publishing and spreading erroneous news is a direct violation of section 17(b) of the Securities and Exchange Ordinance, 1969, (XVII of 1969), in Bangladesh which states

No person shall, for the purpose of inducing, dissuading, effecting, preventing or in any manner influencing or turning to his advantage, the sale or purchase of any security, directly or indirectly make any suggestion or statement as a fact of that which he does not believe to be true.

Any breach of section 17 of the Securities and Exchange Ordinance, 1969, is punishable with imprisonment or with fine. Section 24(1) of the same ordinance states

Whoever contravenes the provision of section 17 shall be punishable with imprisonment for a term which may extend to [five years, or with fine (which shall not be less than five lakh taka)] or with both.

There is even room for legal actions against individuals who were responsible to check an edit the news, for instance, the editor of the newspapers. Section 24(2) of the Securities and Exchange Ordinance, 1969, says:

Where the person guilty of an offence referred to in sub-section (1) is a company or other body corporate, every director, manager or other officer responsible for the conduct of its affairs shall, unless he proves that the offence was committed without his knowledge or that he exercised all diligence to prevent its commission, be deemed to be guilty of the offence.

The journalists and the relevant parties where were supposed to ensure the flow of correct information before readers, can also be trailed under the existing rule which guides journalists and journalism in Bangladesh.

The incident is also punishable as it spreads rumors among investors. In the interest of investors, on September 12, 2001, in exercise of power conferred by section 20A of the Securities and Exchange Ordinance, 1969, the Securities and Exchange Commission (SEC) in Bangladesh issued a directive (SEC/SRMID/2001-1020/1055/Admin-03/01) and asked all person concerned who are directly or indirectly related to or associated with the investors or the securities market or the capital market in any manner, to: refrain from spreading rumor, or helping or assisting in spreading rumor, by any mode or in any form, including by way of behavior or utterance or through misleading, distorting or suppressing material information or facts, which may or is likely to affect the investors or the securities market or the capital market, as the case may be.

The directive also says that contravention of this statute will be punishable with appropriate penal measures which include monetary penalty of minimum one lakh taka under the aforesaid Ordinance.

The incident is even in direct violation of section 4 and 20 of the Code of Conduct, 1993, (2002 as amended) for the newspapers, news agencies and journalists of Bangladesh which was framed under clause 11:2(b) of the Press Council Act, 1974, which states-

Section 4: Truth and accuracy of information available are 
to be ensured as far as possible.

Section 20: The editor is to accept full responsibility for all publications in the newspaper.

In the U.S., the same event is punishable under Section 17(a) of the Securities Act of 1933, Sections 9(a)(4) and 10(b) of the Securities Exchange Act of 1934.

The whole erroneous analysis was corrected in at least two articles on the two different leading newspapers in Bangladesh which were published on October 21 on the daily Financial Express and October 23 on the Daily Star. However, even though SEC in Bangladesh has been the sole agent in taking actions against any contraveners of any sections under the Securities and Exchange Ordinance, 1969, it hasn't taken any steps forward to ensure justice against the false news writers on October 2 and October 3rd, 2012.

\section{Conclusion}

It takes years to instill confidence among investors but needs just a second to destroy it. Arthur Levitt (2000), former chairman of the Securities and Exchange Commission (SEC) in U.S. emphasized on the role of information and the regulatory body in the marketplace, and utters, "Quality information is the lifeblood of strong, vibrant markets. Without it, investor confidence erodes. Liquidity dries up. Fair and efficient markets simply cease to exist. As the quality of information increases exponentially through the internet and other technologies, the quality of that information must be our signal priority."

Of course, an investor shouldn't believe on news blindly. Still responsible journalism is required for a stable market in Bangladesh. Digging-down into an issue is a primary condition for responsible reporting. Spreading fake information, intentionally or unintentionally, will just increase volatility in the stock market. It endangers the vulnerable investors who promptly leap before looking and stand to lose their wealth.

Also false information and inadequate analysis from the mainstream media will discourage fundamental investing, which SEC has been trying to promote among investors. The incident actually raised serious doubt on SEC's effort to control rumor and manipulation in the stock market. When will the regulators actually act as regulators?

Economists have a role to play in educating themselves, the journalists and the legal experts to learn how to judge news and the reaction to it

\section{REFERENCES}

[1] Ahsan, AFM Mainul. (2012, October 23). When will regulators act like regulators? The daily Star, p. 15.

[2] Ahsan, AFM Mainul. (2012, October 21). When will regulators act like regulators? The daily Financial Express, p. 4.
[3] Ahsan, N. (2012, October 2). Banks' stock market exposure set at $40 \mathrm{pc}, \mathrm{BB}$ denied control over SCBs. The daily Financial Express, pp. 1, 7.

[4] Arnold, T., Earl, J. H., \& North, D. S. (2007). Are cover stories effective contrarian indicators? Financial Analysts Journal, 63(2), 70-75.

[5] Barber, B. M., \& D. Loeffler. (1993). The "Dartboard" column: Second-hand information and price pressure. Journal of Financial and Quantitative Analysis, 28, 273-284.

[6] Beneish, M. D. (1991). Stock prices and the dissemination of analysts' recommendations.Journal of Business, 64(3), 393-416.

[7] Chan, W. S. (2003). Stock price reaction to news and no-news: drift and reversal after headlines.ournal of Financial Economics, 70(2), 223-260.

[8] Cutler, D. M., Poterba, J. M., \& Summers, L. H. (1989). What moves stock prices? The Journal of Portfolio Management, 5(3), 4-12.

[9] Desai, H., \& Jain, P. C. (1995). An analysis of the recommendations of the 'Superstar' money managers at Barron's annual roundtable. Journal of Finance, 50(4), 1257-73.

[10] Doong, S. C., Yang, S. Y., \& Chiang, T. C. (2005). Response Asymmetries in Asian Stock Markets. Review of Pacific Basin Financial Markets and Policies, 8(4), 637-657.

[11] Falkenstein, E. (1996). Preferences for stock characteristics as revealed by mutual fund portfolio holdings. Journal of Finance, 51(1), 111-135.

[12] Fang, L., \& Peress, J. (2009). Media coverage and the cross-section of stock returns. The Journal of Finance, 64(5), 2023-2052.

[13] Ferreira, E., \& Smith, S. (2003). 'Wall Street Week': Information or entertainment? Financial Analysts Journal, 59(1), 45-53.

[14] Huberman, G., \& Ragev, T. (2001). Contagious Speculation and a Cure for Cancer: A NonEvent that Made Stock Prices Soar. Journal of Finance, 56(1), 387-396.

[15] Jensen, M.C. (1977, April). The sorry state of news reporting and why it won't be changed. The Bulletin of the American Society of Newspaper Editors, No. 604.

[16] Levitt, A. (2000, April 6). Speech by SEC Chairman: Remarks at the Economic Club of Washington. Retrieved from the Securities and Exchange Commission website http://www.sec.gov/news/speech/spch362.htm

[17] Liang, B. (1999). Price pressure: Evidence from the 'Dartboard' column. Journal of Business, 72(1), 119-134.

[18] Lloyd, D. P., \& Canes, M. (1978). Stock prices and the publication of second-hand information. Journal of Business, 51(1), 43-56.

[19] Mitchell, M. L., \& Mulherin, J. H. (1994). The impact of public information on the stock market. The Journal of Finance, 49(3), 923-950.

[20] Niederhoffer, V. (1971). The analysis of world events and stock prices. The Journal of Finance, 44(2), 193-219. 
[21] Securities and Exchange Commission (SEC) of Bangladesh. (1969, June 28). The Securities and Exchange Ordinance, 1969 (Ordinance No. XVII of 1969). Retrieved from the Securities and Exchange Commission website http://www.secbd.org/F-01.pdf

[22] Securities and Exchange Commission (SEC) of Bangladesh. (2012, September 12). Notification [No.SEC/SRMID/2001-1020/1055/Admin-03/01]. Retrieved from the Securities and Exchange Commission website http://www.secbd.org/F-09.pdf

[23] Solomon, D., Soltes, E. \& Sosyura, D. (2012). Winners in the spotlight: Media coverage of fund holdings as a driver of flows, working paper, University of Southern California.
[24] Takeda, F., \& Yamazaki, H. (2006). Stock price reactions to public TV programs on listed Japanese companies. Economics Bulletin, 13(7), 1-7.

[25] Tetlock, P. C. (2007). Giving content to investor sentiment: The role of media in the stock market. The Journal of Finance, 62(3), 1139-1168.

[26] Tetlock, P. C. (2010). Does Public Financial News Resolve Asymmetric Information? Review of Financial Studies, 23 (9), 3520-3557

[27] Yuan, Y. (2008). Attention and trading, working paper, The University of Iowa. 